Jamen, han tænkte jo... CarlHenrikKoch.Descartes. Centrum 1999, 226 sider. 248 kr.

Der kan være noget irriterende over Descartes. Og det er egentlig ikke så meget Descartes' egen skyld. Snarere er det på grund af den filosofiske dåsemad hans tanker idag bliver serveret som. Aftenskolegendrivelsen af skepticismen, der bruger cogito'et som trampolin og flyver direkte ind i den knaldhårde sjæl-legeme dualisme har godt nok gjort Descartes kendt af de fleste. Men samtidig er han blevet så letfordøjelig, at det kan være vanskeligt at se hvad der skulle have gjort netop ham til en af tidernes største filosoffer. Måske er det det, der er på færde. Hvis det er stor filosofi, så har de fleste nok lidt hjemmespunden lommeuld, de kan kaste ind i kampen.

Selvfølgelig er Descartes ikke helt uden skyld. Metafysiske meditationer er så let at læse, at det også er let at bilde sig ind, at man ved, hvad der er på færde. Descartes har gjort det nemt for os. Vi kan snildt sætte os i hans sted, følge hans tankegang og i den rene erkendelses interesse med et knips ophæve århundreders afstand. Med ét argument og én front er det ingen sag at være filosof.

Alene af den grund bør vi glædes over Carl Henrik Kochs bog om Descartes. Men det er sandelig ikke den eneste grund. Endelig får vi en anstændig fremstilling på dansk, der befrier Descartes fra den filosofiske køledisk og præsenterer ham som den komplekse tænker han var. Internationalt har den hemmelighed længe været kendt og kommer selvfølgelig heller ikke bag på folk herhjemme med en seriøs interesse for Descartes.

Kochs bog er imidlertid en introduktion og dens publikum er primært dem der ønsker at få noget at vide om Descartes, men ikke som det første vil konsultere den udenlandske litteratur. For dette publikum er der tale om en uhyre vigtig bog. Med den i hånden er der ikke længere nogen undskyldning for at forfladige og reducere Descartes' argumenter til café au lait og tilbagelænet filosofisk friløb. Koch sætter argumenterne i sammenhæng i en række glimrende læsninger af Descartes' regler, skriftet om metoden, de metafysiske meditationer og værket om lidenskaberne. På den baggrund får argumenterne en dybde og mening på tværs, der ikke er synlig $\mathrm{i}$ de enkelte værker. En af Kochs store fortjenester er, at han netop præsenterer en sammenhæng, der giver mening og forståelse for hvad Descartes var ude på, hvorfor han var ude på det og hvem han kommunikerede med.

I den forbindelse er det vigtigt at være sig Descartes' gennemgribende naturvidenskabelige interesse bevidst; en interesse der førte til en række vigtige videnskabelige og matematiske erkendelser både på det praktiske og det metodologiske plan og $\mathrm{i}$ kraft deraf kom til at virke stærkt på samtidens videnskab. Heldigvis tager Carl Henrik Koch naturvidenskaben - og religionen for den sags skyld - alvorligt. Man ville da også være en både dårlig historiker og filosof, hvis man ignorerede de emner, der mere end noget andet optog Descartes, og motiverede og prægede hele hans tænkning. Læseren slipper ikke for at blive klar over, at intentionen med det ambitiøse værk Le Monde simpelthen var at forklare alle naturfænomener. Dette inkluderede områder som psykologi, fysiologi og kopernikansk kosmologi, der på baggrund af korpuskelteorien gav Descar- 
tes muligheden for at redegøre for fænomenernes mekaniske årsager. Man er nødt til at kende denne ambition for at kunne forstå hvad der var drivkraften i Descartes' forsøg på at trænge ud af bevidsthedens fængsel og nå frem til erkendelsen af den fysiske verden. Men det er en videnskabshistorisk ligeså vigtig forudsætning for at kunne forstå den newtonianske reaktion mod den cartesianske naturfilosofi. Der er i de senere år kommet en del gode studier af Descartes og videnskaberne (se f.eks. William Shea, The magic of Numbers and Motion - The Scientific Career of René Descartes, Canton 1991 og Stephen Gaukroger, Descartes - an intellectual biography, Oxford 1995, medens vi kan glæde os til Daniel Garber, Descartes Embodied-Reading Cartesian Philosophy through Cartesian Science, Cambridge 2001). Men Koch gør det godt på dansk.

Vi får en god fornemmelse af jesuitternes og Mersenne-netværkets betydning for udbredelsen og diskussionen af naturfilosofien generelt og for Descartes i særdeleshed. Det er næsten mere end man kunne forvente. Men det er på den anden side også nødvendigt, hvis man ønsker at fremvise bare en anelse af den komplekse historie som Descartes' filosofiske og videnskabelige virke skriver sig ind i. Jesuitternes kollosale betydning for udbredelsen af den matematisk-eksperimentelle metode i det 17. århundrede har i de senere år været genstand for en stor videnskabshistorisk interesse (se f.eks. Peter Dear, Mersenne and the Learning of the Schools, Ithaca 1990, samt Discipline and Experience - The Mathematical Way in the Scientific Revolution, Chicago 1995). Også hér er det godt, at vi danskere ikke går glip af denne viden.

Det er klart, at en bog af denne karakter bliver nødt til at udelade visse ting og ind imellem simplificere både historie og argumenter. Alligevel er det lidt ærgerligt, hér at blive præsenteret for det velkendte billede af renæssancens interesse for de okkulte videnskaber overfor det 17 . århundredes skeptiske naturvidenskabelige verdensbillede. Det passer selvfølgelig perfekt ind i skemaet hvor rationalisten Descartes lader fornuftens klare lys skinne og dermed afslører den alkymistiske overtro. Men det er et historisk set problematisk billede. Det er rigtigt, at Descartes både var en arg modstander af alkymien og en vigtig person for det 17 . århundredes videnskabelige verdensbillede. Det sidste var Newton som bekendt også, men han brugte en meget stor del af sit liv og karriere på netop alkymien. Det er i dag almindelig kendt og det er Koch selvfølgelig klar over. Men vi får det ikke at vide $\mathrm{i}$ hans bog og det er en skam, for det kan få visse læsere til at vedblive i troen på, at hele den vestlige verden med ét slag blev gennemført rationalistisk. Det kan ikke engang filosofihistorien holde til, selvom der stadig er nogen der forsøger at slippe afsted med at fortælle den sådan.

Dette er dog en detalje. Carl Henrik Kochs bog Descartes er et velskrevet og velkomment bidrag til at gøre danske læsere klar over, at der hér er mere at hente end skråsikker caféfilosofi. Bogen har endvidere et andet plus. Koch melder klart ud. For ham består filosofi ikke af meninger, men af argumenter. Det kan man så synes om, hvad man vil - især på baggrund af Descartes' reaktion på Gassendis kritik af meditationerne - men man er ikke i tvivl om, hvor man har Koch. Og det er ubetinget en fordel.

Bogen udgør første bind i Cen- 


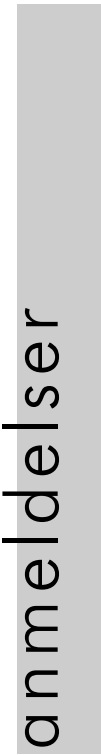

trums nye serie De Store Filosoffer. Der er planlagt yderligere bind om Platon, Aristoteles, Hume, Adorno og Wittgenstein. Det er selvfølgelig fint nok. Den første bog i serien er en kærkommen hjælp til at kvalificere undervisning og selvstudier i filosofiens historie. Men den bog vi rent faktisk mangler nu vi har Kochs bog om Descartes er en om Newton. Den er der virkelig brug for. Men hvornår får vi den?

Peter C. Kjærgaard

\section{Emanuel Swedenborg}

Emanuel Swedenborg, Drømmebogen,

Oversæettelse ved Jette Frantzen, Hans Reitzels Forlag, Filosofibiblioteket, København 1999, 106 s. $148 \mathrm{kr}$.

\section{Emanuel Swedenborg} (1688-1772) inkarnerer om nogen en nordisk barok universallærd, ligesom en Leibniz på kontinentet. Han var en fremstående svensk videnskabsmand, vel bevandret i samtidens videnskabelige litteratur, uddannet i England og på kontinentet og med et kosmopolitisk kontaktnet; han havde en høj stjerne hos suverænen (Karl XII.), og var ansat i den dengang teknologisk avancerede og statspolitisk altafgørende bjergværksdrift.

Imidlertid var han som baroklærd netop også en bredtfavnende tænker, og - via en lige så tidstypisk religiøs åbenbaring - i sit senværk en lige så fremtrædende mystisk teolog, der endnu i dag har sin religiøse proselytter rundt om i form af swedenborgske selskaber. I udpræget grad er det netop disse mystisk-religiøse visioner, der i dag påkalder den største interesse. Hans navn er kendt blandt religionshistorikere, hvorimod de fleste af hans videnskabelige teorier og indsigter hurtigt blev overhalet af de store videnskabelige fremskridt i det 18. og 19. århundrede. Af selvsamme grund har han aldrig fanget den samme opmærksomhed blandt videnskabshistorikere, hvilket man kan beklage. For en bredere idéhistorisk forståelse kunne det være al mulig grund til også at få den videnskabelige del af Swedenborgs værk belyst.

Når det ikke har været tilfældet skyldes det formodentlig, at videnskabshistorien typisk har beskæftiget sig med den sejrrige videnskab med vægt på de i bagklogskabens lys avancerede genier, de store tænkere, de korrekte antagelser, forestillinger og begreber, der bidrog til videnskabens fremskridt. Det har nemlig den fordel, at man kan læse retrospektivt. Problemet er blot, at den metafysiske forestilling om en unilineær og enhedslig Videnskabs (Fornufts) fremskridt deklasserer alle medierende mellemregninger til kleingeister og hvileperioder - og Swedenborg er her en af de uheldige. Han er ikke nået op på højde med sine europæiske kollegaer. En sådan forestilling om videnskaben hører imidlertid ikke til i Swedenborgs egen tid, men er af nyere dato, og for videnskabshistoriens vedkommende taler vi her primært om det 19. århundrede og dets videnskabsapoteose. Men da var manden allerede diskvalificeret af sit mystisk-religiøse engagement, fordi religion og videnskab var blevet til gensidigt udelukkende størrelser. I det 17. århundrede - og endog langt ind i det 18. århundrede - havde de intellektuelle imidlertid 